UDK 130.123.1+159.923

DOI https://doi.org/10.30970/2307-1664.2019.24.7

\title{
PHENOMENON OF LONELINESS: FROM FEELING TO LIFE STRATEGY
}

\author{
Vitalii Malimon \\ Ivano-Frankivsk National Technical University of Oil and Gas, \\ Department of Public Administration and Management \\ Korolya Danyla str., 15, 76018, Ivano-Frankivsk, Ukraine
}

Foreign and domestic researches of the phenomenon of loneliness as a feeling and life strategy are studied in the article. Loneliness appears as a multidimensional ambiguous phenomenon of human existence, a meaningful component of the structure "man-world", as a part and manifestation of the spiritual world. Scientific approaches of studying loneliness and criteria of types and forms specification of loneliness are analyzed.

Nowadays, loneliness has a global nature, it is one of the present-day megatrends and has both positive sides (creates a space for self-actualization, allows to lead a more colorful social, cultural and sexual life) and negative sides (it can have negative consequences for the physical, mental and spiritual health of a person).

Modern society is devoid of ideological basis, therefore, each individual in it is guided by its own goals and interests, which makes it alienated from meanings and ideals. And this leads to a situation of confusion, the search for schemes of behavior, which in principle are absent, to attempts to get rid of outdated stereotypes, which are replaced by new ones. Now a person seeks to «have» and not «be» (E. Fromm), seeks to get rid of responsibility for his own actions, which inevitably leads to internal conflicts and contradictions.

Established that historically formed zones of social and personal irresponsibility. Accordingly, many people simply choose the strategy of "escape to solitude", not being able and not wanting to take responsibility for their lives and the lives of others.

There is made an attempt to characterize loneliness as conscious life strategy related with the formation of own space of comfortable life, avoidance of undesirable social contacts, spiritual values and searching. The experience of loneliness creates opportunities for a broader vision of old problems, the formation of new life strategies, which contributes to the decision to choose in the direction of selfimprovement and change of life situation, or refusal to change.

Modern man, in order not to experience the state of loneliness, first of all must overcome its alienation from society, to carry out the process of self-transcendence.

Key words: loneliness, positive loneliness, negative loneliness, solitude, life strategy.

From ancient times till now outstanding scholars have been interested in an issue of loneliness and it has taken a significant part in the development of worldwide philosophical and psychological thought. Philosophers and psychologists of different epochs have tried to define the phenomenon of loneliness, to show its essential characteristics, to characterize cross-conditionality of loneliness and the level of individual's socialization, to figure out its positive and negative aspects. Today loneliness is a multi-leveled phenomenon, which includes existential, cognitive, communicative and value aspects.

Loneliness as a phenomenon appears in T. Brenner's, C. Moustakas', F. Nietzsche's, J. Ortega-i-Gasset's, V. Frankl's, S. Freud's, E. Fromm's, M. Heidegger's works. The scientists explore questions of living through loneliness as internal specific feeling and having a sense of loosing inner world by a person, the question of the duration of loneliness and the causes for

(C) V. Malimon, 2019 
its emergence. Existentialists connect the evolution of a human life-world with establishment of the conscious attitude to own loneliness (realizing of loneliness define the relationship with the environment).

The review of philosophical works convinces that the phenomenon of loneliness is multidimensional. M. Movchan singles out philosophical aspects of this phenomenon: a) loneliness-solitude, that is voluntary avoiding contacts with people for focusing on some business, thing, yourself (R. Emerson, H. Thoreau and others); b) loneliness-homelessness, that is uncertainty of the meaning and role of human's being; misery of a person in the infinity; the lack of established harmony of person with world (M. Buber, S. Kierkegaard, F. Nietzsche, B. Pascal and others); c) loneliness-responsibility, that is the "doomness" of every person upon an independent choice of modus operandi, impossibility of shifting responsibility for own choice on the others (existentialism); d) loneliness-non-fusion, that is the starting and insuperable silos of existence of "I" from the other beings (existentialism, phenomenology).

The main aim of the article is the review of phenomenon of loneliness as a feeling and chosen life strategy. For achieving the aim some particular tasks are assigned: to disclose scientific approaches of revealing ontological basis of the phenomenon of loneliness; to give prominence to forms, expressions of loneliness and to characterize loneliness as conscious or unconscious life strategy.

Etymologically the word "loneliness" originates from Greek "monas" (a unit, single) which is used for defining fundamental elements of being in an ancient and classical philosophy. It meant "to stay alone", "to be without others" because they had leaved us or we had leaved them to have monastic life. The dictionary of the Ukrainian language states "loneliness" as "property and condition", as "realizing of that kind of condition". As for the lexical unit of "loneliness" (lane, lonely), its definition is "the one, who remained, lives alone, without anyone" [2, p. 171].

In the psychological dictionary (A.V. Petrovsky and M.H. Yaroshevska's edition) loneliness is defined as one of psychogenic factors, that affect the emotional state of a person who is under changed (unaccustomed) conditions of isolation from other people.

The state of loneliness is person's dealing with loss of internal integrity and external harmony with the world. It is expressed in violation of harmony between desirable and achieved quality of social communication.

Leticia Ann Peploe, Maria Miceli and Bruce Morash believe that “...loneliness is a complicated feeling which completely owes a person, her emotions, thoughts, actions".

German philosopher F. Nietzsche outlines that loneliness shouldn't be considered as a drama and perceive it with fear or despair. In his opinion, "a person shouldn't be scared of her/ himself, but vice versa ought to stay alone to better understand hem/himself, his/her inner world, to get rich spiritually". To F. Nietzsche's mind, "a person should realize the positive sense of loneliness, but people's attitude to it has an individual character. Thus, some people tend to excessive immersion into a state of loneliness through reassessment of importance of being lonely, and others choose loneliness to get the conditions for self-improving"... "for one person loneliness is the escape of sick person; for others it is the escape from sick people" [6, p. 216].

Consonant are views of J. Ortega-i-Gasset, who defines some positive moments of person's loneliness. Particularly, he argues that "a person in the process of solitude pays attention to her/himself, to the development of own "I", tries to realize own identity and eventually to improve own skills". He notes that "a person can from time to time stop his/her normal activities and dive deep into her/himself to listen to the inner voice, focus on oneself" [7, p. 162]. During such immersion a person improves oneself, becomes more confident what lets him/her to join external world again and successfully solve problems that have been too hard earlier [8, p. 29-30]. 
M. Heidegger claims that the state of loneliness helps a person to understand own solitude and to think about existential problems of his/her life. Dwelling on the state of loneliness, the person is alone, estranges oneself from the external world, directs own consciousness to God.

Direct communication with other people is a condition of overcoming loneliness in M. Heidegger's philosophy, but active communicative connection do not always help to solve this problem.

According to the existential model (C. Moustakas, V. Frankl, I. Yalom and others) solitude and loneliness are integral to human being; moreover, people are lonely by nature. V. Frankl stresses the need of division of concepts «to be lonely» and "to feel lonely". He understands the feeling of loneliness as experience of the fear to be really lonely. To be really lonely is conditioned by the very factor of human being, that we are given to stand in existential situations such as birth, death, doom. The author believes that it is impossible to consider loneliness only from a negative point of view because it itself can be a source of creative attitude to life. C. Moustakas considers the fear of loneliness as a display of defense mechanisms. He claims that "people who feel fear are fail in solving their own life assignments. They either drain themselves superficial relationships with other or do some fruitless and unconstructive soul-searching" [10, p. 19]. The author stresses the meaning of difference between "vanity of loneliness" and "true loneliness". Vanity of loneliness as a system of defense mechanisms moves a person away of solving important life issues, constantly encourages him/her to strive for activity for the activity with other people. True loneliness arises from a particular reality of lonely being and person's facing with border life circumstances (birth, death, life changing, tragedies), that s/he deals alone with, points to a positive aspect of living through loneliness, which gives us an opportunity to look at the situation from a new angle, to change values, to find a meaning of own life, to make appropriate decisions concerning own behavior and to get to know the other you [8, p. 33-34].

O. Neumoyeva [11] argues that, on the one hand, loneliness is related with the deformation of different person's relationships, but on the other hand, this is a phenomenon which gives you an opportunity to plunge into a personal reflection, into consideration of life issues. The author distinguishes four types of loneliness according to internal and external orientation: internal negative loneliness, external negative loneliness, internal positive loneliness, and external positive loneliness.

Studying loneliness over space and time, K. Goldberg states that "loneliness is a refusal from the present moment, from its opportunities and requirements. The loss of this «present» leads to a violated glance at the time, i. e. the feeling that the present time is frozen, it is infinite and has no future. This violated perception of time weakens the ability of the subject to interpersonal communication, which further more strengthens the feeling of loneliness" [12, p. 302]. $\mathrm{K}$. Goldberg includes to the time characteristics of ontological violation faultiness (past), shame (present) and fear (future).

In works of S. Trubnikova loneliness is presented as a phenomenon which is a person's experience of the subjective impossibility or reluctance to have adequate feedback and acceptance oneself by other people [13]. This can have either negative (exclusion), or positive (release, solitude) subjective aspects. Researcher also suggests species classification of loneliness (exclusion, loneliness, self-exclusion, solitude).

Negative dealing with loneliness (exclusion and self-exclusion) can be transferred to its subjective positive type, i. e. solitude by means of purposeful psych-correctional work, in which due to restructuring of consciousness changes of the attitude to oneself and to the world, increase of empathy and actualization of its behavioral manifestations the psychological stability of the individual is formed as a dynamic balance of contradictory trends in identification and separation [14]. 
Researcher Y. Zavorotnykh [15] distinguishes three levels of loneliness as a subjective living through, i. e. negative loneliness (low level); comfortable loneliness (middle level); destructive loneliness (high level). She proves that loneliness as a subjective living through relatively independent of volume and character of interpersonal contacts and is defined by his/her characteristics. Thus, for example, a person, who has a family, who has a wide system of social connections, from the social point of view is not lonely, but during the life s/he faces this feeling.

Y. Shvalb and O. Dancheva [16] distinguish three main forms of loneliness:

1. Ceremonies, rituals, parenting strategy of being alone that took place practically in all tribes and nations. We can find the rituals of "introduction to loneliness" almost in any traditional culture. Archaic, primitive societies, where the person's life proceeds in the eyes of tribesmen, consider a rank of circumstances when a person has the right to stay alone, and also themes that it is not accepted to speak about and even more to ask. Those rituals had a significant psychological meaning. They were the kind of means which give person an opportunity, to comprehend and realize oneself.

2. Punishment by loneliness expressed in exile from the genus that condemns the death of the guilty. Violation of the important for the tribe rules, taboo (ban) in most of the primitive indigenous people were punished either with death or exile, and the second one was considered more severe. For example, if the main dogmata were violated, religion used the tool of excommunication and anathema. Similarly, any state imposes a penalty of imprisonment for violation of the law.

In social groups typical examples are widely used boycotts, group obstructions to social stigma. All of the methods are intended to physically and, most importantly, psychologically isolate an individual.

Voluntary solitude of individuals, asceticism. With drawal from everyday affairs, loneliness which implies internal concentration and overcoming the lower impulses are the essential characteristics of asceticism. The consolidation of such form in culture had led to the fact that solitude and loneliness became a necessary condition of a fully secession, development of the person, the formation of an individual reflexivity and contemplative, spiritual enrichment and the ability for creativity. Loneliness potentially carries the possibility of realizing all the best that a person has [17, p. 211-212].

T. Brennen [18] distinguishes such types of manifestation of loneliness, as general loneliness, emotional loneliness that is related to weakening, collapse or threat of loss the relationship with someone close; social loneliness that is related to the inaccessibility or with the loss of social ties in society for one or another reason; the realizing of disparity between real ties and existed inner standards, that are formed in relationships with someone close, is of a great importance; spiritual loneliness is related to searching of own identity and the meaning of life.

N. Khamitov [19] divides loneliness into internal and external. People of internal loneliness are considered themselves to be deeply lonely. Such people are not externally isolated from others, but feel lonely, subjectively are living through the isolation from others in the background of objective person's including in the interpersonal relationship. External loneliness is a real absence of a specific loved one close by, objective isolation from social interaction with others.

V. Serma [20] argues that the notion of loneliness is related to experience the situations that are subjectively treated as undesirable, individually unacceptable for a person because of deficit of communication and positive intimate relationships with surrounding people. With the ending of the situation, "ends" loneliness. In appearance of loneliness author distinguishes a "person's factor" and stresses the own perception of the situation that depends on individual's characteristics. Based on the results of the study V. Serma claims that people who describe themselves as lonely ones get fairly high scores, for example, on the scale of "hostility"; they have a stronger 
sense of regret and guilt in relation to the past, they often build too idealistic plans for the future [8, p. 41].

On the time basis of the individual experience of the state of loneliness V. Serma distinguishes: past loneliness that is expressed in short-term bouts of loneliness, which completely and without a trace pass, leaving no trace; situational that appears as a result of any stressful events in a person's life (someone close or break intimate relationships). After a short time of distress, a situationally lonely individual accepts his loss and partially or completely overcomes the feeling of loneliness that has arisen; chronic loneliness that occurs when an individual cannot establish for a long period of life satisfactory relationships with people of importance to him [20].

According to K. Abulkhanova-Slavska, the life path of a person has common problems for all people, but the way to solve them is deeply individual, and therefore the life path of each person is individual. From the spontaneous way of life a person can move to one that $\mathrm{s} / \mathrm{he}$ will determine oneself. But the essence of this definition is in making decisions about the choice of conditions, direction of life, in choosing the education, the profession that will best meet the characteristics of his/her personality, the desires, the abilities, in building an appropriate life strategy [21, p. 7]. According to the researcher, social life has not prompted the development of social thinking either in terms of deep awareness of social problems or in terms of personal solutions for many years in our society. There was no responsibility for decision-making, which usually broadens the horizons of the individual, allows you to see solutions [21, p. 258].

Nowadays, a person feels lonely regardless of the number of people around him/her: friends, associates, relatives, casual acquaintances. Moreover, the feeling of loneliness, the constant experience of the absence and even the impossibility of establishing close spiritual and intimate relations with other people begin to determine the objective state of a person in society. And the experience of loneliness creates opportunities for a broader vision of old problems, the formation of new life strategies, which contributes to the decision to choose in the direction of self-improvement and change of life situation, or refusal to change.

Thus, loneliness appears as a multidimensional ambiguous phenomenon of human existence, a meaningful component of the structure «man-world», as a part and manifestation of the spiritual world. Loneliness of a modern man becomes not only a feeling, but also a conscious strategy of life, full of inner meaning. This conscious choice can be associated with the formation of a comfortable space of life, avoiding unwanted social contacts, spiritual quest and values.

\section{References}

1. Мовчан М. Самотність як полівекторний феномен: філософсько-антропологічний дискурс. URL: http://www.info-library.com.ua/books-text-11854.html.

2. Мельничук О.С. Етимологічний словник української мови Т. 5 (Р-Т). Київ, 2006.704 с.

3. Психология. Словарь / Под общ. ред. А.В. Петровского, М.Г. Ярошевского. 2-е изд., испр. и доп. Москва : Политиздат, 1990. 494 с.

4. Гусейнова H.O. Зарубіжні та вітчизняні дослідження переживання самотності. URL: http://ekhsuir.kspu.edu/bitstream/123456789/665/1/стаття\%202\%20\%20Гусейнова.pdf.

5. Пепло Л.Э., Мицели М., Мораш Б. Одиночество и самооценка. Лабиринты одиночества: Пер. с англ. / Сост., общ. ред. и предисл. Н.Е. Покровского. Москва : Прогресс, 1989. C. $169-191$.

6. Ницше Ф. Так говорил Заратустра. Москва : Мартин, 2005. 416 с.

7. Ортега-и-Гассет Х. Углубление в себя и обращенность вовне. Философские науки. 1991. № 5. C. $158-173$.

8. Бедан В.Б. Індивідуально-типологічні особливості схильності особистості до переживання самотності : дис. ... канд. псих. наук. Одеса, 2018. 319 с. 
9. Хайдеггер М. Бытие и время. Москва : AdMarginem, 1997. 451 с.

10. Moustakas C.E. (1972). Loneliness and love. Englewood Cliffs, N.J. : Prentice-Hall. 146 p.

11. Неумоева Е.В. Одиночество как общественно-историческое явление и как явление индивидуальной жизни. Гуманитарный вектор. Вестник Забайкальского отделения Академии гуманитарных наук. 2004. № 1-2 (10-13). С. 23-29.

12. Джонг-Гирвельд Д., Раадшелдерс Д. Типы одиночества. Лабиринты одиночества : сборник науч. тр. Москва : Прогресс, 1989. С. 301-319.

13. Трубникова С.Г. Психология одиночества: генезис, виды, проявления : дис. ... канд. психол. наук. Москва, 1999. 195 с.

14. Ващенко І.В., Айвазян Л.Ю. Проблема діагностичного виміру суб'єктивного відчуття самотності. URL: http://www.soc.univ.kiev.ua/sites/default/files/library/elopen/ actprob16_110-116.pdf.

15. Заворотных Е.Н. Социально-психологические особенности одиночества как субъективного переживания : дис. ... канд. психол. наук. Санкт-Петербург, 2009. 254 с.

16. Швалб Ю.М., Данчева О.В. Одиночество: Социально-психологические проблемы. Киев : Украина, 1991. $270 \mathrm{c}$.

17. Помазова О.В. Самотність як психологічний феномен. URL: https:/eprints.oa.edu. ua/2549/1/Pomazova\%20O.V.pdf.

18. Brennan T. Loneliness at Adolescence Loneliness. A Sourcebook of Current Theory, Research and Therapy / Ed. L.A. Peplau \& Perlman. A Wiley Interscience Publication, 1982. PP. 269-290.

19. Хамитов Н.В. Философия одиночества. Опыт вживания в проблему. Одиночество женское и мужское. Киев : Наук. думка, 1995. 170 с.

20. Серма В. Некоторые ситуативные и личностные корреляты одиночества. Лабиринты одиночества / пер. с англ. сост., общ. ред. и предисл. Н.Е. Покровского. Москва : Прогресс, 1989. С. 231-237.

21. Абульханова-Славская К.А. Стратегия жизни. Москва : Мысль, 1991. 299 с.

\title{
ФЕНОМЕН САМОТНОСТІ: ВІД ПОЧУТТЯ ДО СТРАТЕГІЇ ЖИТТЯ
}

\author{
Віталій Малімон \\ Івано-Франківський національний технічний університет нафти і газу \\ кафедра публічного управління та адміністрування \\ вул. Короля Данила, 15, 76018, Івано-Франківськ, Україна
}

У статті розглядаються зарубіжні та вітчизняні дослідження феномена самотності як почуття і стратегії життя. Самотність визначається як багатовимірний неоднозначний феномен людського буття, змістовна складова частина структури «людина-світ» як частина і прояв душевного світу. Аналізуються наукові підходи щодо дослідження самотності та критерії щодо виокремлення видів і форм самотності.

У наш час самотність набуває глобального характеру, виступає одним із мегатрендів сьогодення і має як позитивні (створює простір для самоактуалізації, дає змогу вести більш насичене соціальне, культурне та сексуальне життя), так і негативні сторони (може мати негативні наслідки для фізичного, психічного й духовного здоров ‘ людини).

Сучасне суспільство позбавлене ідеологічної основи, тому кожен індивід у ньому керується власними цілями та інтересами, що робить його відчуженим від смислів та ідеалів. I це приводить до ситуації розгубленості, до пошуку схем поведінки, які, у принципі, відсутні, до спроб позбутися застарілих стереотипів, які заміщаються новими. Тепер людина прагне «мати», а не «бути» (Е. Фромм), прагне позбутися відповідальності за власні вчинки, що неминуче приводить до внутрішніх конфліктів та суперечностей. 
Вісник Львівського університету. Серія філос.-політолог. студії. 2019. Випуск 24

Встановлено, що історично сформувалися зони соціальної і особистісної безвідповідальності. Відповідно, багато людей просто вибирають стратегію «втечі в самотність», не вміючи і не бажаючи брати на себе відповідальність за своє життя та життя інших людей.

Зроблено спробу охарактеризувати самотність як усвідомлену стратегію життя, що пов'язана 3 формуванням свого простору комфортного життя, уникнення небажаних соціальних контактів, духовними пошуками та цінностями. Переживання самотності розглядається як можливість ширшого бачення старих проблем, формування нових стратегій життя, що сприяє прийняттю рішення про вибір у напрямі самовдосконалення і зміни життєвої ситуації, або відмову від змін.

Сучасна людина, щоб не переживати стан самотності, має, насамперед, подолати своє відчуження від суспільства, здійснити процес самотрансценденції.

Ключові слова: самотність, позитивна самотність, негативна самотність, усамітнення, стратегія життя. 